\title{
Why Does China Attempt to Internationalise the Renminbi?
}

Yin-Wong Cheung, Guonan Ma and

Robert N. McCauley ${ }^{1}$

\section{Introduction}

The global financial crisis shone a spotlight on the US dollar as a pivot in international finance as it gave rise to a dollar shortage in 2008 more acute than that of the 1950s (McCauley and McGuire 2009; McGuire and von Peter 2009). The US authorities relieved the dollar shortage by entering into dollar swaps with central banks on an unprecedentedly broad scale and, with major central banks, in unlimited amounts (CGFS 2010). Before long, market concerns switched to possible excess dollar liquidity as the US Federal Reserve carried out repeated programs of large-scale bond purchases (the second dubbed the 'QE2' [quantitative easing 2] policy).

The temporary dollar shortage and the subsequent worries over a dollar glut served to highlight the dependence of the international financial system on a currency subject to national management. In particular, the crisis put at risk international trade between countries outside the United States as banks in either country had difficulty rolling over dollar liabilities in the interbank market in order to finance their trade. More recently, economies outside the United States have tried to build dams to divert dollar inflows away (see IMF 2011; McCauley 2010). To a system engineer, it might appear to be a negligent design that left such a 'single point of failure' in the international financial system.

\section{Policy-driven internationalisation of the RMB}

Against this backdrop, a number of recent policy initiatives suggest that the Chinese authorities have adopted a proactive strategy to promote the international use of the renminbi (RMB). By currency internationalisation, we mean the use of a currency by nonresidents to invoice trade, to make payments and to denominate assets and liabilities. The archetypal transaction in an internationalised currency is a non-resident selling a bond denominated in the currency to another non-resident in a market located outside the country ('offshore market'). The change in the Chinese approach is evident in the contrast, for instance, between Dobson and Masson (published in 2009 but written in early 2008) and Gao and Yu (2011) (also see Chen and Cheung 2011; Cheung et al. 2011). In what follows, we first discuss the possible rationales for this strategy, contrasting the experiences of China and Japan, and then briefly sketch the policies undertaken so far. 


\section{Rationale and strategy}

Why has policy turned to promote the international use of the RMB? Most commentary has interpreted this strategy as deriving from doubts about the US dollar as a store of value or as intending to build a sphere of financial influence in East Asia. There might be something to these interpretations. We emphasise instead, however, a strategy to share the specific risk imbedded in China's international balance sheet-namely, a large and rapidly increasing foreign exchange exposure. This exposure derives from the combination of China's openness to direct investment from the rest of the world, its current account surpluses, and the lack of internationalisation of the RMB.

Like many advanced economies, China has a short position in its own currency and a long position in other currencies (counting inward direct investment and inward portfolio equity as RMB liabilities). Such positions can arise from no more than a simple cross-border exchange of equities, with balanced current accounts all around. To illustrate, one can imagine two islands of equal size, population and fertility but distant enough from each other to enjoy different weather from year to year. They agree to exchange each year a share of each other's harvests (that is, they swap equities). As a result, each naturally has a long position in the other's harvest (currency). In fact, China has allowed the rest of the world to share more of its harvest than has Japan. In particular, non-residents have a stake in China's equities (direct investment and portfolio) equivalent to 24 per cent of China's gross domestic product (GDP) (Ma and Zhou 2009), while non-residents of Japan have a stake in Japan's equities of only 17 per cent of Japan's GDP.

China, like Japan, has a large second source of its net long position in foreign currency: persistently large current account surpluses. Since the early 2000s, these flows have cumulated into a stock known as the net international investment position: the difference between the nation's external assets and liabilities. Current account surpluses build up a net creditor position, while current account deficits build up a net debtor position. As can be seen in Figure 4.1, China's net international asset position is converging with that of Japan, at 40-50 per cent of GDP. While Japan's position built up over a generation, China's position has in just a decade swung from a net debtor of some 10 per cent of GDP to a net creditor of 37 per cent in 2009 (Ma and Zhou 2009).

For China, the rest of the world's equity position and the net international investment position simply sum to China's long position in foreign currency. This sum was approaching 60 per cent of China's GDP in 2009 (Figure 4.1). Most of this risk is concentrated in the government sector in the form of foreign exchange reserves financed by RMB liabilities (required reserves and central bank bills). If some of China's claims on the rest of the world were denominated in $\mathrm{RMB}$, this would reduce its long foreign currency position from this level. But none of China's claims on the rest of the world is RMB denominated. 
Figure 4.1 Net international investment positions and net long foreign exchange position proxy

As percentage of GDP

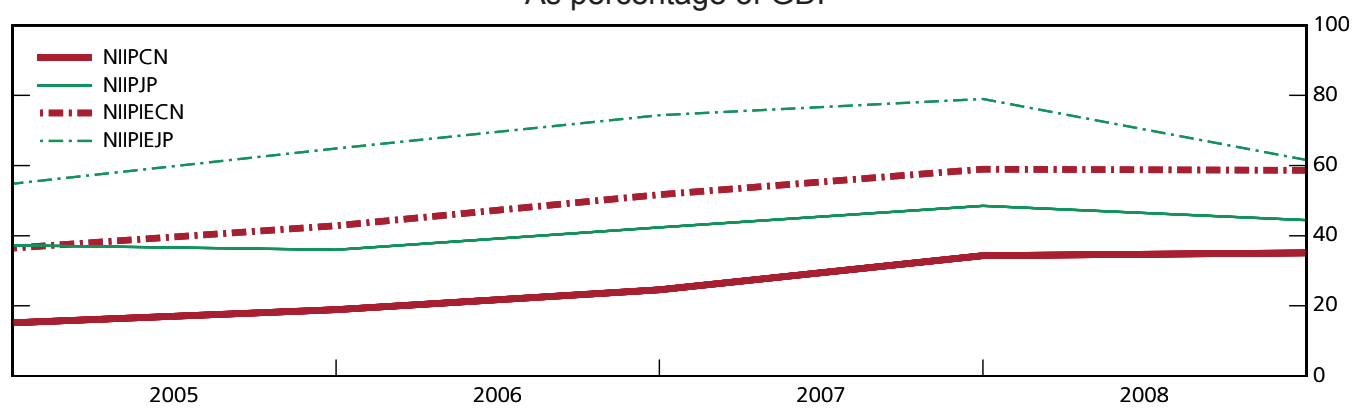

Note: Net international investment positions (NIIPCN for China and NIIPJP for Japan) and net long foreign exchange position proxy (NIIPIECN for China and NIIPIEJP for Japan) as a percentage of GDP.

Sources: The People's Bank of China, various years; Bank of Japan, various years.

Japan shows how the international use of a creditor country's currency can allow the rest of the world to share in a creditor country's foreign currency risk. Even a modest internationalisation of the yen means that the rest of the world uses the yen to some extent to denominate both liabilities and assets, allowing the rest of the world to share Japan's aggregate foreign exchange exposure. In particular, Lane and Shambaugh (2010) estimate that Japan has net yen claims on the rest of the world to the extent of a modest 2 per cent of GDP. Taking this into account, China, in its short life as a substantial creditor nation, has already racked up as much aggregate foreign exchange exposure in relation to GDP as Japan (that is, by 2009 China's dotted line in Figure 4.1 would reach Japan's if Japan's net yen claims were subtracted).

How has Japan accumulated net claims denominated in yen on the rest of the world? On the asset side of Japan's international balance sheet, there are official reserves of about $\$ 1$ trillion-by definition, all held in foreign currency. But in addition-and in contrast with China-Japanese insurance companies, pension funds and mutual funds hold a stock of securities twice the size of the official reserves. The Bank of Japan reports that of these almost one-third - amounting to 11.6 per cent of GDP — was yen denominated.

In sum, even though China's net international assets as a share of GDP remain smaller than those of Japan, its aggregate long position in foreign exchange is already as large as that of Japan, if not larger. This owes both to the greater share of GDP in foreign holdings of equities in China resulting from large foreign direct investment (FDI) inflows for the past two decades and to a lack of internationalisation of the RMB hitherto. Given the combination of openness to FDI and capital controls that has kept the rest of the world from borrowing RMB, China has an acutely skewed international balance sheet: long foreign currency, not least the dollar, and short domestic currency.

The medium-term strategy of denominating some of China's external claims in the RMB would go in the direction of normalising this skewed position. We call this strategy of denominating China's claims on the rest of the world in RMB one of 'renminbising' China's international assets. Let us be clear: the renminbisation of China's international assets is a particular aspect of the broader process of RMB internationalisation. As noted above, 
internationalisation happens when non-residents use the RMB, whether to lend or to borrow. The renminbisation of China's foreign claims requires that non-residents borrow in $R M B$ from residents. We stress that the resulting sharing of the foreign exchange risk currently imbedded in China's international balance sheet provides a key motive for the broader process of internationalising the RMB.

Conceivably, over the medium term, something like one-third of China's non-reserve holdings of securities might come to be denominated in $\mathrm{RMB}$, or an even higher proportion if China's efforts meet with greater success than Japan's. In this scenario, China's sovereign wealth fund, pension funds and insurance companies could to a significant extent diversify away from Chinese credit risk, by buying RMB securities issued by non-Chinese firms, banks and sovereigns, without taking on foreign currency risk.

In addition to the private holding of bonds issued by non-residents in domestic currency, China could lessen its aggregate exchange rate risk by denominating more of its official external claims in RMB. For instance, the Japan Bank for International Cooperation, an official international development agency, lends yen to foreign governments and firms. Its loans in yen reached $\$ 119$ billion in 2008, compared with its foreign currency loans of $\$ 41$ billion. The yen loans amount to close to 3 per cent of Japan's GDP about the mid-2000s. As China expands its aid operations in Asia, Africa and Latin America, it will have considerable scope to denominate its official international claims in RMB.

While denominating and settling trade in domestic currency might encourage greater international use of the RMB over the medium term, it is unlikely to directly spread the foreign exchange risk of China to the rest of the world in any significant way. Taking again Japan as an example, Takagi (2011) reports that in 2002, 36.7 per cent of Japanese exports were yen denominated, compared with 25.5 per cent on the import side. For China to accumulate substantial net trade claims on the rest of the world, an even larger asymmetry between exports and imports would be required and this is not likely. ${ }^{2}$ That said, the invoicing of trade in RMB could play a supporting role by encouraging the rest of the world to issue bonds and take on official debt denominated in RMB, thereby working to encourage the global sharing of the foreign exchange risk in China's international balance sheet.

Eventually, the internationalisation of the RMB - its use to denominate bonds, official credits and trade - could result in the RMB gaining heft as a currency in the foreign exchange market. There is ample room for the RMB to advance in this regard as it is used more for financial transactions and internationally. In April 2010, global central banks reported global daily trading in RMB of $\$ 34$ billion, with most of that occurring outside China and in non-deliverable form. ${ }^{3}$ Even if turnover in China is underreported, limited use for financial transactions and by non-residents kept global RMB trading about level with the current account transactions of China - a very low ratio for a country of China's income per capita (Figure 4.2). In contrast, the Indian rupee turned over at a rate about 10 times the current account transactions of India-implying much higher financial transactions in the Indian case. Given India's income per capita, the rupee punches well above India's weight (McCauley 2011; McCauley and Scatigna 2011). Indeed, highly internationalised currencies such as the dollar, euro and yen turn over something like 100 times their respective current transactions. In other words, the internationalisation of the RMB has a long way to go. 
Figure 4.2 Ratio of foreign exchange turnover to trade in relation to GDP per capita, April 2010

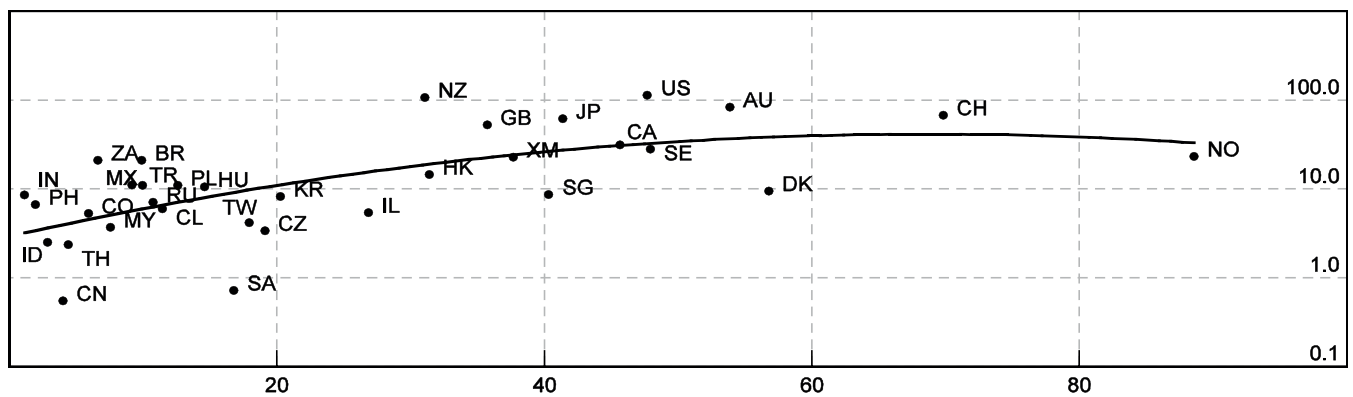

Notes: Horizontal axis = GDP per capita, in thousands of US dollars; vertical axis = ratio of foreign exchange turnover to trade, semi-logarithmic scale. Foreign exchange turnover includes not only over-the-counter but also exchange-traded turnover, which is most significant for the Brazilian real, the Indian rupee and the Korean won.

Sources: IMF, various years; FOW TRADEdata; Futures Industry Association, various years; BIS Triennial Central Bank Survey of Foreign Exchange and Derivatives Market Activity, various years; authors' estimates.

The medium-term strategy of replacing dollar claims on the rest of the world with RMB claims would also have implications for the euro's exchange rate. An alternative strategy to re-denominating China's external claims would be to diversify holdings away from the dollar and into other major currencies such as the euro and the yen. If China sold dollardenominated bonds and bought euro-denominated bonds then the euro would come under upward pressure against the dollar (Blanchard et al. 2005). ${ }^{4}$ China's shifting of its claims from the dollar to the RMB would not exert such pressure on the dollar/euro rate.

The two distinct strategies of renminbising foreign assets and diversification to the benefit of the euro can be pursued simultaneously and can also be combined. Thus, the People's Bank of China (PBC) has undertaken to purchase notes from the International Monetary Fund (IMF) denominated in special drawing rights (SDR) in an amount up to SDR32 billion over the three years to 25 August 2012; and the Chinese authorities have also urged consideration of including the RMB in the SDR basket. Were China ultimately to provide dollars to the IMF in exchange for such bonds, it would be diversifying from the dollar into the euro, and to a lesser extent the yen and sterling, since these currencies along with the dollar form the SDR basket. This should be understood as more diversification across the major currencies rather than as a use of the RMB to re-denominate China's claims on the rest of the world. ${ }^{5}$

If the strategy of internationalising the RMB were pursued to the point of making the currency's role in international finance commensurate with the weight of China as a trading nation, it would have implications for the IMF's SDR. The last five-year review of the SDR valuation, in December 2010 (IMF 2010b), set out two criteria for inclusion of a currency in the SDR. First is whether the scale of exports of goods and services places a currency among the top-four currency areas in the world (treating the euro area as just one of the top four). Second is whether the currency is freely usable, meaning that it is widely used and widely traded in the foreign exchange market. 
These two criteria cut quite differently for the RMB. The first criterion places it in the SDR basket in the 2010 review - albeit with a weight that would reflect near-zero holdings of RMB in official reserves. Satisfying the second criterion could, however, be a much more distant prospect. In particular, while bilateral trading agreements could satisfy the "widely used' aspect, the 'widely traded' aspect of the RMB has a long way to go (as shown above). With the Presidents of France and the United States having publicly considered inclusion of the RMB in the SDR, and a working group in the Group of 20 (G20) having taken up the question, it is not safe to make predictions regarding the conditions or the pace of such inclusion. For present purposes, what should be emphasised is that, once the RMB is included in the SDR basket, China's shifting claims on the rest of the world from dollars into SDR would combine the strategies of currency diversification across major currencies and of re-denominating external claims in RMB.

\section{Policies to promote greater international use of the RMB}

In an apparent departure from its previous hesitancy and go-slow stance, the Chinese Government has, since late 2008, proactively rolled out a number of measures aimed at increasing the international use of the RMB. First, the $\mathrm{PBC}$ has signed bilateral RMB currency swap agreements with eight central banks, totalling more than RMB800 billion (US $\$ 120$ billion). Such agreements permit swaps between the RMB and the local currency of the counterparty for a maturity of up to three years, which is extendable (Table 4.1). Memories of the dollar liquidity shortage and contracting trade flows during the global financial turmoil might potentially give this policy initiative some traction, though the practical challenges remain formidable. The PBC reports that, so far, RMB30 billion of these RMB800 billion swap agreements have been activated (PBC 2011).

Table 4.1 Bilateral currency swap agreements with the People's Bank of China

\begin{tabular}{|l|l|l|}
\hline Date of agreement & Counterparty & Size of swap lines \\
\hline 12 December 2008 & Bank of Korea & RMB180 billion and KRW38 trillion \\
\hline 20 January 2009 & Hong Kong Monetary Authority & RMB200 billion and HK\$227 billion \\
\hline 8 February 2009 & Bank Negara Malaysia & RMB80 billion and MYR40 billion \\
\hline 11 March 2009 & National Bank of the Republic of Belarus & RMB 20 billion and BYR8000 billion \\
\hline 23 March 2009 & Bank Indonesia & RMB100 billion and IDR175 trillion \\
\hline 2 April 2009 & Central Bank of Argentina & RMB70 billion and ARS38 billion \\
\hline 9 June 2010 & The Central Bank of Iceland & RMB3.5 billion and ISK66 billion \\
\hline 23 July 2010 & Monetary Authority of Singapore & RMB150 billion and SG \$30 billion \\
\hline
\end{tabular}

Note: All agreements have a maturity of three years and are renewable.

Source: PBC web site (<www.pbc.gov.cn>).

These swaps can be seen as backstopping the second initiative, denominating and settling trade in RMB. In April 2009, the Chinese State Council approved a pilot scheme for cross-border trade settlement in RMB, initially involving Shanghai and four other Chinese cities in Guangdong Province, on the one hand, and Hong Kong on the other. Since mid2010, the pilot has expanded to cover 20 of the 30 Chinese provinces and to involve any overseas trading partner. By the end of 2010, Chinese exporters involved in the pilot scheme 
increased to more than 40000 firms from the initial hundreds. In dollar terms, the volume of RMB trade settlements has risen from 0.2 per cent of China's total trade flows in 2009 to some 3 per cent in 2010. Cui et al. (2009) estimate that as much as 30 per cent of China's US $\$ 2.5$ trillion annual exports and imports could be settled in RMB if there was full capital account convertibility. As noted above, this experiment in cross-border trade settlement in $\mathrm{RMB}$ would result in both RMB-denominated foreign claims and RMB-denominated liabilities for China. So far, the Hong Kong Monetary Authority (HKMA) is known to have activated RMB10 billion of its RMB300 billion swap line with the PBC to facilitate the smooth operation of cross-border RMB trade settlement.

The recent Chinese imports settled in RMB have, in combination with the longer-standing provision for Hong Kong residents to switch deposits into RMB, led to a significant buildup of RMB funds in Hong Kong. Banks in Hong Kong first started offering RMB deposits in 2004, which were initially available only to Hong Kong residents who were able to leave standing orders to acquire up to RMB20 000 a day per account - a daily quota of RMB conversion that remains valid today. The RMB deposit base in Hong Kong is, however, increasingly fed by RMB paid to settle RMB-denominated Chinese imports. Thus, RMB deposits rose by a factor of four in 2010, as both more Hong Kong residents converted deposits and more exporters took payment in RMB, in part owing to strong expectations of RMB appreciation. As of the end of 2010, RMB deposits in Hong Kong stood at 5 per cent of Hong Kong's total deposits but still remained below 0.5 per cent of China's total domestic bank deposits. ${ }^{6}$

Third, with the explicit endorsement of Beijing, Hong Kong is shaping up as the hub for the offshore deliverable RMB market. Two-thirds of total RMB trade settlements involve Hong Kong. Hong Kong banks may now open accounts and provide services related to RMB for any local or overseas corporate client. Tellingly, the Chinese Government has now issued RMB-denominated bonds in Hong Kong, in addition to those issued by Chinese and foreign banks, international organisations and multinational corporations (Table 4.2). Although in many cases such 'Dim Sum bonds' - RMB-denominated bonds issued by residents or nonresidents offshore in Hong Kong - would only increase China's RMB-denominated foreign liabilities (or equivalently increase China's long foreign currency position), the move might promote the role of the RMB in offshore financial transactions generally. The RMB is traded freely in Hong Kong's spot and forward markets, with a daily trading volume between US $\$ 300$ million and US\$1 billion in recent months. In a nutshell, the RMB, once in Hong Kong, is almost fully convertible and can behave quite differently from its onshore cousin in terms of yields and pricing.

Fourth, in parallel with the growth of the offshore RMB market, incremental internationalisation of the RMB bond market inside China can bring the benefits of greater diversity of issuers and investors to a large but not very liquid market. Recall that in 2005, the International Financial Corporation and the Asian Development Bank issued RMB1.13 billion and RMB1 billion of Panda bonds (RMB-denominated bonds issued by non-residents onshore), respectively, with the requirement that the proceeds be used to fund domestic lending and investing (Table 4.3). Panda bond issuance helps to widen the range of credit exposures for domestic investors in RMB-denominated bonds. The rule requiring the proceeds of Panda issues to be used in China was changed in September 2010. 
Now, international institutions, with the approval of the State Administration of Foreign Exchange (SAFE), may remit overseas the proceeds from Panda bond sales either in RMB or in foreign currencies. This policy change represents another step in the experiment of liberalising the capital account and widening the international use of the RMB and, crucially, gives China RMB-denominated foreign claims on the rest of the world (Yu 2008).

Table 4.2 RMB-denominated bonds issued in Hong Kong

\begin{tabular}{|c|c|c|c|c|}
\hline Date & Issuer & $\begin{array}{l}\text { Amount } \\
\text { (RMB bn) }\end{array}$ & $\begin{array}{c}\text { Coupon rate } \\
(\%)\end{array}$ & $\begin{array}{c}\text { Duration } \\
\text { (years) }\end{array}$ \\
\hline July 2007 & China Development Bank & 5.0 & 3.00 & 2 \\
\hline August 2007 & Export-Import Bank of China & 2.0 & 3.05 & 2 \\
\hline \multirow[t]{2}{*}{ September 2007} & Bank of China & \multirow{2}{*}{3.0} & 3.15 & 2 \\
\hline & & & 3.35 & 3 \\
\hline July 2008 & Bank of Communications & 3.0 & 3.25 & 2 \\
\hline August 2008 & China Construction Bank & 3.0 & 3.24 & 2 \\
\hline August 2008 & Export-Import Bank of China & 3.0 & 3.40 & 3 \\
\hline \multirow[t]{2}{*}{ September 2008} & Bank of China & \multirow{2}{*}{3.0} & 3.25 & 2 \\
\hline & & & 3.40 & 3 \\
\hline June 2009 & HSBC China & 1.0 & SHIBOR + 38bp & 2 \\
\hline July 2009 & BEA China & 4.0 & 2.80 & 2 \\
\hline August 2009 & China Development Bank & 2.0 & 2.45 & 2 \\
\hline August 2009 & China Development Bank & 1.0 & SHIBOR + 30bp & 2 \\
\hline August 2009 & HSBC & 2.0 & 2.60 & 2 \\
\hline September 2009 & China Ministry of Finance 3 & \multirow{3}{*}{6.0} & 2.25 & 2 \\
\hline September 2009 & China Ministry of Finance 2.5 & & 2.70 & 3 \\
\hline September 2009 & China Ministry of Finance 0.5 & & 3.30 & 5 \\
\hline July 2010 & Hopewell Highway Infrastructure & 1.4 & 2.98 & 3 \\
\hline August 2010 & CITIC International Bank & 0.5 & 2.68 & 1 \\
\hline August 2010 & HSBC CD & 0.1 & 2.00 & 0.5 \\
\hline August 2010 & McDonald's & 0.2 & 3.00 & 3 \\
\hline September 2010 & Bank of China & 2.2 & 2.65 & 2 \\
\hline September 2010 & Bank of China & 2.8 & 2.90 & 3 \\
\hline October 2010 & Asian Development Bank & 1.2 & 2.85 & 10 \\
\hline October 2010 & China Development Bank & 2.0 & $\begin{array}{l}\text { 3M SHIBOR 5-day } \\
\text { average +10bp }\end{array}$ & 3 \\
\hline October 2010 & SINOTRUK & 2.7 & 2.95 & 2 \\
\hline November 2010 & China Development Bank & 3.0 & 2.7 & 3 \\
\hline November 2010 & UBS (HK) & 0.2 & 2.50 & 2 \\
\hline November 2010 & China Resources Power & 1.0 & 2.90 & 3 \\
\hline November 2010 & China Resources Power & 1.0 & 3.75 & 5 \\
\hline November 2010 & China Merchants Group (HK) & 0.7 & 2.90 & 3 \\
\hline
\end{tabular}




\begin{tabular}{|l|l|c|c|c|}
\hline Date & Issuer & $\begin{array}{c}\text { Amount } \\
\text { (RMB bn) }\end{array}$ & $\begin{array}{c}\text { Coupon rate } \\
(\%)\end{array}$ & $\begin{array}{c}\text { Duration } \\
\text { (years) }\end{array}$ \\
\hline December 2010 & Caterpillar & 1.0 & 2.0 & 2 \\
\hline December 2010 & China Ministry of Finance & 2.0 & 1.0 & 3 \\
\hline December 2010 & China Ministry of Finance & 2.0 & 1.8 & 5 \\
\hline December 2010 & China Ministry of Finance & 1.0 & 2.48 & 10 \\
\hline December 2010 & Export-Import Bank of China & 1.0 & 1.95 & 2 \\
\hline December 2010 & Export-Import Bank of China & 4.0 & 2.65 & 3 \\
\hline December 2010 & ANZ Bank & 0.2 & 1.45 & 2 \\
\hline December 2010 & Galaxy Entertainment Group & 1.38 & 4.625 & 3 \\
\hline December 2010 & China Power International Development & 0.8 & 3.2 & 5 \\
\hline December 2010 & VTB Capital & 1.0 & 2.95 & 3 \\
\hline January 2011 & World Bank & 0.5 & 0.95 & 2 \\
\hline January 2011 & Sinochem & 3.5 & 1.8 & 3 \\
\hline January 2011 & International Finance Corporation & 0.15 & 1.8 & 5 \\
\hline February 2011 & PCD Stores & 0.75 & 5.25 & 3 \\
\hline February 2011 & YFY Cayman & 0.3 & 3.1 & 3 \\
\hline February 2011 & Beijing Capital Land & 1.15 & 4.75 & 3 \\
\hline February 2011 & Road King & 1.3 & 6.0 & 3 \\
\hline
\end{tabular}

Sources: Authors' calculations; web sites of HKMA (<www.info.gov.hk/hkma/>) and PBC (<www.pbc.gov.cn>).

Table 4.3 Panda bonds issued in China

\begin{tabular}{|l|l|c|c|c|}
\hline Issue date & Issuers & $\begin{array}{c}\text { Size } \\
\text { (RMB bn) }\end{array}$ & Rate (\%) & $\begin{array}{c}\text { Maturity } \\
\text { (years) }\end{array}$ \\
\hline October 2005 & Asian Development Bank & 1.00 & 3.34 & 10 \\
\hline October 2005 & International Finance Corporation & 1.13 & 3.40 & 10 \\
\hline November 2006 & International Finance Corporation & 0.87 & 3.20 & 7 \\
\hline December 2009 & Asian Development Bank & 1.00 & 4.20 & 10 \\
\hline May 2010 & Bank of Tokyo-Mitsubishi UFJ (China) & 1.00 & Negotiated & 2 \\
\hline
\end{tabular}

Note: Panda bonds that had been issued as of January 2011 are presented.

Source: Authors' own estimates.

On the investor side, the Chinese authorities have allowed access by designated foreign banks to the interbank bond market. This is a clear step forward from the very limited bond market access afforded through the Qualified Foreign Institutional Investor scheme. This scheme allowed investors to buy only those bonds listed on the stock exchange, whereas the interbank bond market provides the more liquid trading platform and features better prices. To date, some 20 overseas banks have won approval, subject to a quota, to invest offshore RMB accumulated through trade settlement into China's huge onshore interbank bond markets. 
This new possibility highlights how offshore holdings of RMB could become more attractive if they were endowed with greater cross-border mobility. It is well known that, hitherto, China's capital control has been substantial and extensive (Cheung and Qian 2010; Ma and McCauley 2008; Tsang 2010). The internationalisation measures described above have made RMB outflows sizeable and relatively easy. Once offshore, RMB flows back onshore have been restricted mainly to the trade channel (and other specially approved mechanisms such as case-by-case FDI using RMB). Renminbi-linked but dollar-settled bonds have been sold by Chinese real estate firms in Hong Kong precisely because of the anticipation of greater ease in getting the SAFE approval for dollars rather than for RMB. The Chinese Government accepting dollars more readily than RMB points to a very cautious management of offshore RMB returning onshore. The interbank bond access, therefore, represents notable progress.

While much of the discussion above of Chinese policy concerns its advantages for the Chinese, it should be remembered that it takes two to tango. Why should external obligors eventually accept the denomination of their liabilities in RMB? Some aid recipients might look the gift-horse in the mouth by resisting concessional credit in RMB. Thus, the Chinese Government could follow Japan's lead and extend foreign aid loans in RMB in the future. For instance, the China Development Bank (CDB 2009) reports that 4.7 per cent of its RMB2.9 trillion loans are made outside the mainland. These amounted to RMB135 billionequivalent to about US $\$ 20$ billion. Were such loans to be extended in the future, they could be denominated in RMB.

In general, borrowers in the rest of the world would be bound to ask themselves two questions before agreeing to borrow in RMB. First, is such borrowing subject to the risk of rapid appreciation against other currencies? After all, at present the Chinese bear the balance sheet risk of a sudden appreciation of the RMB against foreign currencies. Were parties outside China to share in this risk then the incentives for China to prevent such an appreciation would be to some extent attenuated (a moral hazard point: the distribution of risk might affect behaviour). Second, a more subtle question, but still relevant to external parties considering whether to borrow $\mathrm{RMB}$, is whether it is likely to track the US dollar closely?

The following two sections take up these questions. Should potential RMB obligors outside China be deterred by the prospect of a sharp appreciation of the RMB? Or should the RMB be expected to shadow the US dollar so closely as to offer little diversification advantage as a currency in which to denominate obligations?

\section{Risk of a sharp appreciation to renminbisation}

One precondition for renminbisation is that borrowers in other countries are willing to hold their liabilities denominated in RMB. If the RMB is perceived to be severely undervalued and subject to a prospective sharp appreciation, firms or sovereigns outside China would be unwilling to hold liabilities denominated in RMB, which would stymie the process of RMB internationalisation. 
The concern over - or in some cases, hope of - a sharp appreciation is not uncommon among observers who argue that the RMB is substantially undervalued. Yet the observed $\mathrm{RMB}$ movements and exchange rate policies in recent years do not reinforce the likelihood of this outcome. After a temporary suspension during the recent global financial crisis, China, on 19 June 2010, returned to the 'managed floating exchange regime' adopted in 2005. As in 2005, the recently stated policy calls for steady and gradual change in the value of the RMB (PBC 2010b), and resembles an upward crawl against the dollar (Ma and McCauley 2011a, 2011b).

There are both academic and policy studies that suggest the RMB is substantially undervalued. Indeed, the 2010 IMF Article IV Consultation Staff Report (IMF 2010a) assesses that the RMB 'remains substantially below the level that is consistent with mediumterm fundamentals' (emphasis added). The Chinese authorities, however, offered alternative interpretations of evidence that the report used to draw the undervaluation assessment. The report's assessment was also not agreed to by several directors of the IMF Executive Board (IMF 2010a).

There is no shortage of estimates of the degree of RMB misalignment, and the estimated extent of undervaluation varies considerably from one study to another. The differences in the estimates come not only from different model specifications but also from models with similar theoretical underpinnings.

Table 4.4 presents some recent estimates of the degree of RMB misalignment. Most of these estimates were obtained from typical theoretical frameworks including relative purchasing power parity (PPP), the Penn effect, the productivity approach, the behavioural equilibrium exchange rate model, the fundamental equilibrium exchange rate approach, and the macroeconomic balance effect approach. ${ }^{7}$ One striking observation is the dispersion of these misalignment estimates, ranging from a 49 per cent undervaluation to a 36 per cent overvaluation. Even if we drop the ad-hoc deviation from the trend estimates, the remaining estimates are still spread over a rather wide range. Most of these studies, surprisingly, overlook or understate the notorious difficulty of determining the extent of RMB undervaluation. 
Table 4.4 Some recent estimates of the degree of RMB misalignment

\begin{tabular}{|l|l|l|}
\hline Estimate (\%) & As of & Source \\
\hline-41 & 14 October 2010 & The Economist (2010), Big Mac index \\
\hline-33 & March 2009 & Cline and Williamson (2010), FEER \\
\hline$-31^{*}$ & 2005 & Subramanian (2010), Penn effect \\
\hline$-21^{\star *}$ & End of 2008 & Goldstein and Lardy (2009), external balance \\
\hline$-17.5^{* *}$ & 2009 & Wang and Hu (2010), FEER, external balance \\
\hline-10 & Q1 2010 & Tenengauzer (2010), external balance \\
\hline-2.56 & Q4 2009 & Stupnytska et al. (2009), BEER \\
\hline 5 & 2008 & Cheung et al. (2010b) \\
\hline 13.4 & Q4 2008 & Hu and Chen (2010), FEER \\
\hline 16.8 & September 2009 & $\begin{array}{l}\text { Cheung et al. (2010b), relative PPP, real US\$/RMB bilateral } \\
\text { exchange rate }\end{array}$ \\
\hline 36 & December 2009 & Cheung et al. (2010b), real PPP, trade-weighted exchange rate \\
\hline
\end{tabular}

* the average of estimates from adjusted data

** the average of estimates

Notes: FEER refers to fundamental equilibrium exchange rate and BEER refers to behavioural equilibrium exchange rate. As for the Penn effect, see the discussion in the text.

The overarching issue is, of course, how to define a currency's appropriate (or, in economic jargon, its equilibrium) value. In addition to the difficulty that economists have encountered in predicting exchange rate changes (Meese and Rogoff 1983), they have had a hard time agreeing on a benchmark for an appropriate exchange rate value (Cheung et al. 2005). A direct implication of this literature is that the prospect of having a commonly agreed framework to assess RMB valuation is pretty unpromising. In the absence of a consensus exchange rate model, potential borrowers in the RMB will naturally interpret with great caution assertions about the level of the RMB's undervaluation.

Figure 4.3 illustrates some of the difficulties in assessing the degree of RMB misalignment. It depicts the IMF's trade-weighted real effective exchange rate index for the period 19802009 with a higher value meaning a stronger Chinese currency. The sample mean and linear trend estimated over the available sample are also plotted. One typical measure of currency misalignment is the deviation from a deterministic trend. In this case, the deviation from the trend indicates a 36 per cent overvaluation and the deviation from the mean gives a 7.5 per cent undervaluation at the beginning of 2010. 
Figure 4.3 Misalignment via linear trends, real exchange rate (trade weighted)

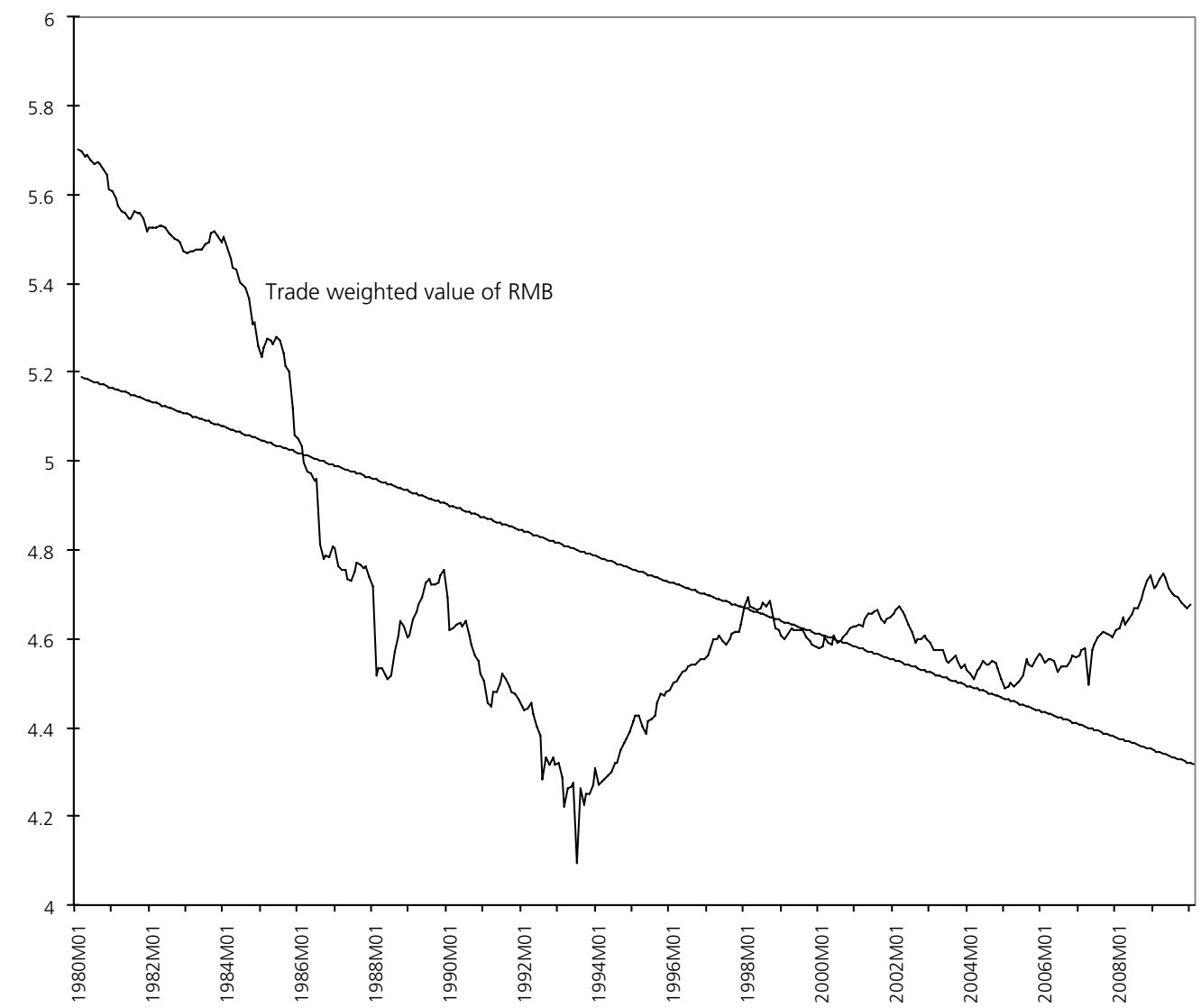

The relevance of Figure 4.3 is not its implied misalignment estimates but the fragility and sensitivity of these estimates, which in turn offer a glimpse into the reason behind the widely diverse RMB misalignment estimates in Table 4.4. For instance, the use of different measures of 'trend' could lead to very different misalignment estimates. It is obvious that, if we start with the sample period from 1994, the trend deviation measure will yield some substantial undervaluation estimates. Further, different misalignment estimates could be generated by using different price deflators and by using a broken trend or a nonlinear trend instead of a linear trend. For more elaborated frameworks for assessing currency valuation, the analogues of these sources of ambiguities are the specification uncertainty, the sample period selection, and the choice of data series. Thus, a proper assessment of currency misalignment requires agreement on both theory and empirics.

Cheung et al. (2007) highlight the uncertainty surrounding any calculation of the extent of RMB undervaluation. We recap their argument based on the well-known Penn effect, which refers to the robust empirical positive association between national price levels and real per capita incomes across countries documented by a series of University of Pennsylvania studies (Kravis and Lipsey 1983, 1987; Kravis et al. 1978; Samuelson 1994; 
Summers and Heston 1991). One message is that while one can obtain a quantitatively large misalignment estimate, it is hard to argue that the estimated misalignment amounts to statistically significant evidence of undervaluation.

The point is illustrated in Figure 4.4, which traces out: 1) the actual real RMB exchange rate (the diamond line; higher values indicate a stronger, more appreciated RMB); 2) the 'equilibrium' real exchange rate predicted by the empirical exchange rate and income relationship (the solid line); and 3) the one and two standard error bands associated with the predicted equilibrium rates (the dotted lines). Undervaluation is observed when the actual rate is lower than the predicted rate.

Figure 4.4 Actual and predicted RMB values

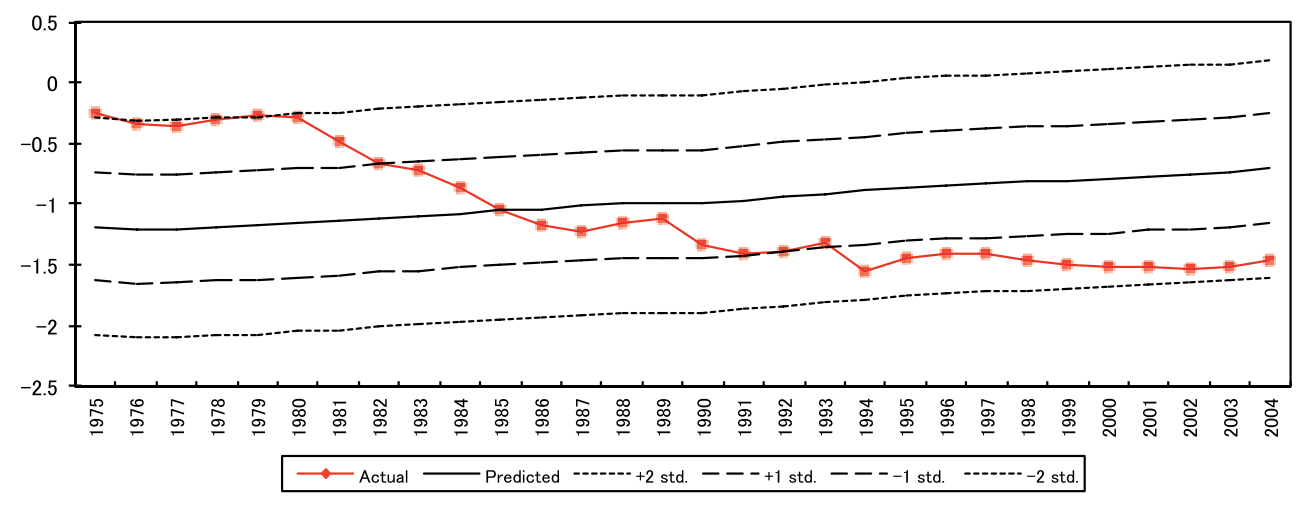

Source: Authors' estimations.

One important feature of Figure 4.4 is the width of the standard error bands. The wide range underscores the uncertainty surrounding exchange rate determination. The evidence suggests that, in the 2000s, the RMB was undervalued and its value was less than its predicted equilibrium value - but also that its value remained within the two standard error band. This is the criterion that applied economists commonly use to assess if the evidence is statistically significant or not.

Key to this analysis is the reliability of the data on the Chinese real income level. The data used to generate results presented in Figure 4.4 were based on the 1993 International Comparison Program benchmark. Some emerging economies including China and India did not fully participate in the 1993 International Comparison Program. Thus, the data for these countries are 'projected' and, hence, subject to some unknown errors.

In 2008, the World Bank, in cooperation with the Asian Development Bank, reported new relative price estimates that are derived from the 2005 International Comparison Program benchmark. ${ }^{8}$ Cheung et al. (2010b) assess the implication of this data revision for assessing RMB misalignment. Essentially, they re-estimate the Penn effect regression using data derived from the new relative price estimates, which are deemed to offer a more accurate description of China's economy. 
The implications for misalignment estimation are summarised in Figure 4.5, which has the same format as Figure 4.4. The startling outcome is that these new data imply a substantial reduction in the estimated degree of RMB undervaluation; most of the recent misalignment estimates are within the one standard error band. Indeed, the most recent data give a 5 per cent overvaluation estimate of the RMB in 2008.

Figure 4.5 Actual and predicted RMB values based on 2010 vintage data

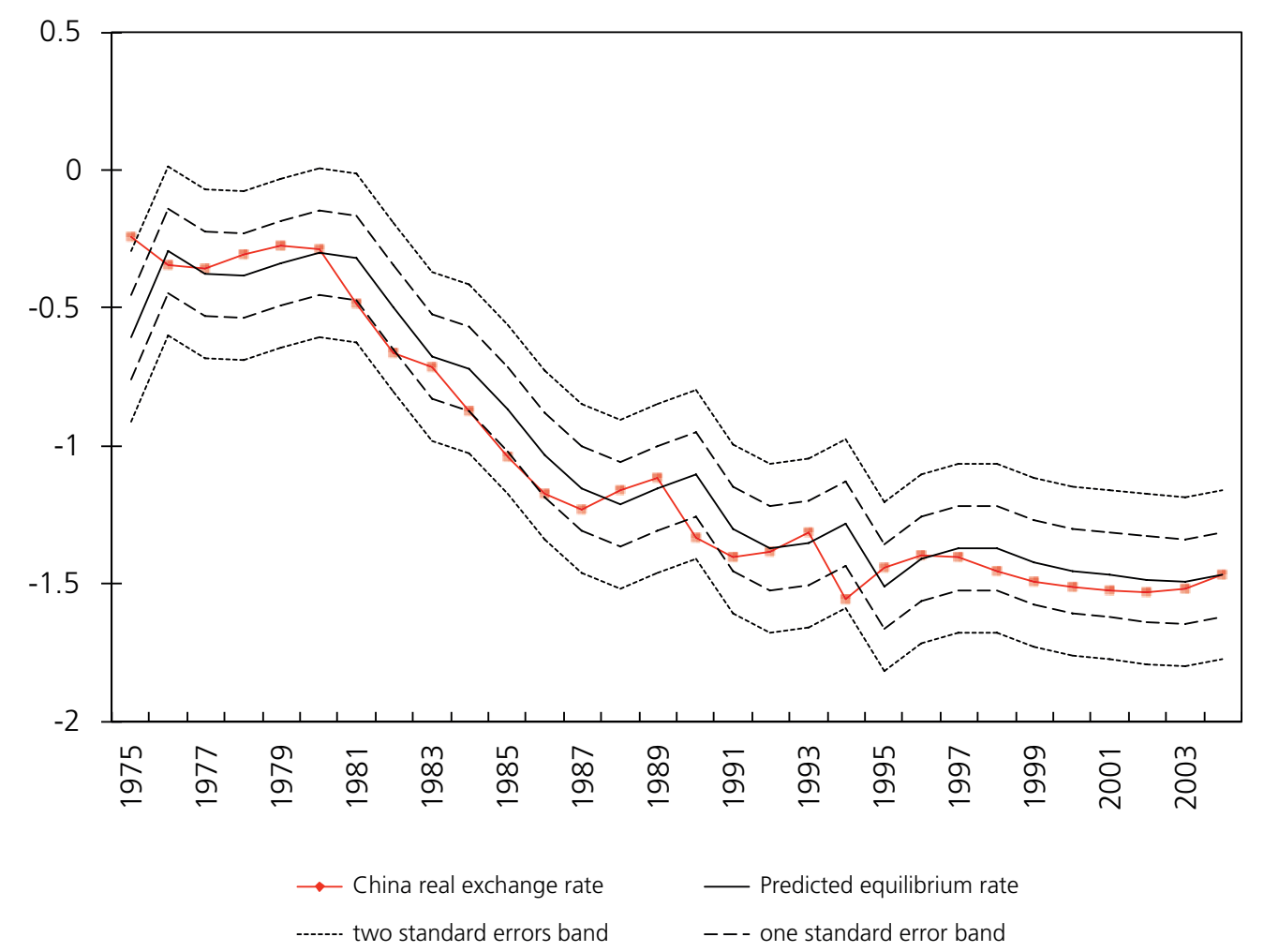

That is, previously reported undervaluation estimates could be spurious results from using unrevised and now outdated information to evaluate the current economic environment. This data revision and its consequence for the estimation highlight another dimension of the difficulty in accurately assessing the degree of RMB misalignment.

Do these studies imply the RMB is not undervalued? No, weak empirical evidence does not exclude the possibility of undervaluation. The evidence, in fact, is so weak that we could not reject a wide range of hypotheses related to RMB valuation. Instead of arguing for undervaluation or overvaluation, the relevant message is that it is hard to deliver a $\mathrm{RMB}$ undervaluation verdict that meets the standards of careful empirical work expected of academic study.

Even under thick smoke, governments and firms in China's trading-partner countries still have to make a decision about whether to denominate their debts in RMB. In practice, policymakers and corporate treasurers operate in the here and now of the real world and 
not in the academic universe. The difficulty of drawing a clear verdict does not necessarily mean that there is no undervaluation. Nonetheless, it is prudent to avoid formulating strong policy recommendations based on weak empirical evidence.

An alternative approach is to ask the question: from a practical point of view, should we choose the currency denomination of our debt based on the assumption that the RMB carries a massive and potentially costly jump risk? Given the contradictory empirical evidence presented above and elsewhere, reputation matters. In the economic arena, the Chinese authorities are perceived to follow a gradualist approach and to focus on economic stability. A massive RMB revaluation is seen as posing the risk of serious disruption to China's domestic economy and its extensive production and trade networks with other Asian economies. If the recent experience of gradualism is given weight, the prospect of a substantial RMB revaluation should not block the internationalisation of the RMB.

\section{The US dollar link and the renminbisation of China's external assets}

The prevailing view among both market participants and academics has been that the RMB has moved from a simple dollar peg (1994-2005) to an upward crawl against the dollar (mid-2005 to mid-2008) and then back to a dollar peg during the global financial crisis of mid-2008 to mid-2010. If this were so then the internationalisation of the RMB would surely be inhibited by the prospect of a continued link to the dollar. All the liquidity advantages of US-dollar markets would favour inertia, while the RMB as a store of value would offer, by hypothesis, little but the dollar plus noise. The RMB would amount to no more than an illiquid dollar, which is likely to be unpopular among market participants. Worse yet, if its course in mid-2005 to mid-2008 and since mid-2010 were just an upward crawl against the dollar, it would work against obligors taking on RMB debt. Why borrow in the RMB if, as things stand, there would be little or no interest savings compared with dollar debt but the prospect of a trend appreciation against the dollar?

This conventional wisdom, with its possible negative implication for RMB internationalisation, is not well founded. If, indeed, the Chinese authorities have made an intellectual and practical break from the dollar, and even if the global financial crisis led them to revert to the dollar for a time, the RMB stands a better chance of being accepted by obligors. Ma and McCauley (2011a, 2011b) present evidence that the post-July 2005 regime for the RMB was not just a crawling dollar peg. Instead, from mid-2006 and mid-2008, the Chinese authorities appeared to manage the RMB against its trade-weighted basket in a manner similar to the longstanding management of the Singapore dollar. Several arguments lend support to this interpretation of the evolving post-2005 RMB regime.

First, two Chinese flagship central bank reports (PBC 2008; SAFE 2008) cited the Bank for International Settlements (BIS) effective exchange rate measure of the RMB when discussing trends in the RMB exchange rate, suggesting increased attention given to the effective exchange rate in RMB management. This signalled a break from the tradition established 
during the East Asian financial crisis. Indeed, as argued by Fung et al. (2009), in terms of maintaining both trade competitiveness and price stability, effective RMB stability would generally serve China better than bilateral dollar stability.

Second, during 2006-08, the effective RMB and the effective US dollar moved mostly in opposite directions - amply demonstrating the lost influence of the dollar cycle on the effective RMB during this episode (Figure 4.6). This is another sign of the RMB moving away from a pure dollar peg.

Figure 4.6 Nominal effective exchange rates of the RMB and US dollar $(2005=100)^{\mathrm{a}}$

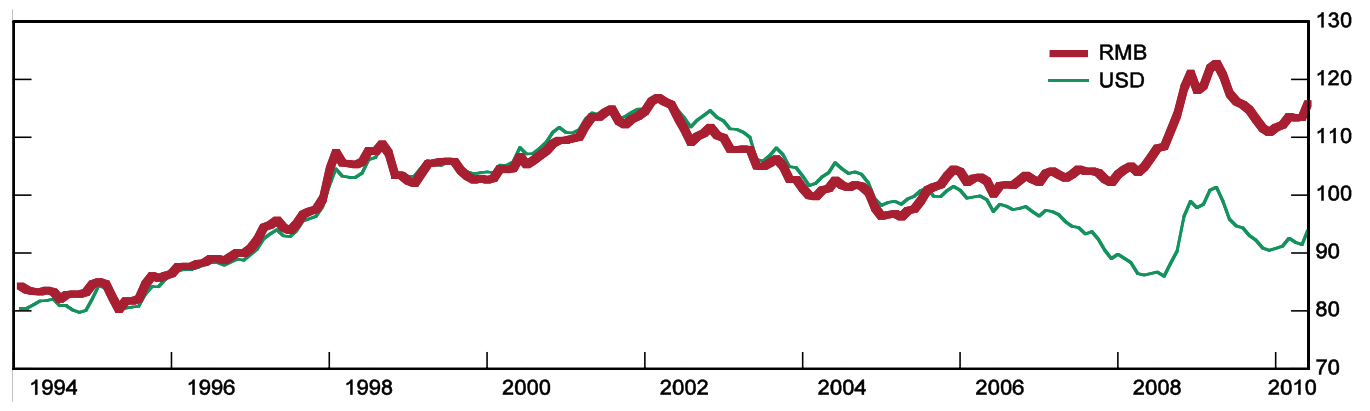

a BIS broad indices based on 58 economies, monthly data.

Source: BIS web site (<www.bis.org/>).

Figure 4.7 Nominal effective exchange rate for the Chinese RMB index $(2005=100)^{\text {a }}$
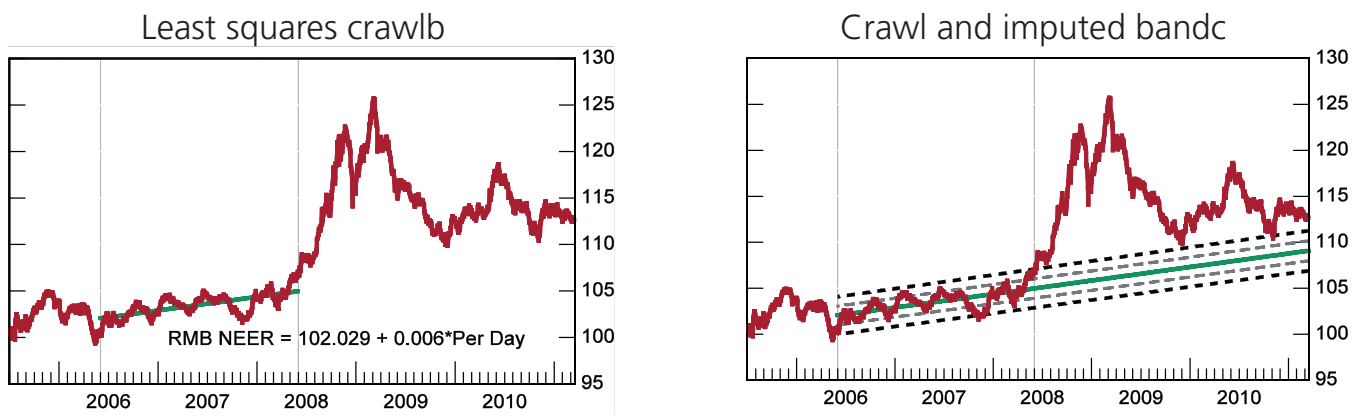

a BIS effective exchange rate broad index based on 58 economies.

b The trend line is estimated over the two-year period of 1 June 2006 to 30 May 2008, regressing the RMB NEER against a tradingday trend. The adjusted $\mathrm{R}$-squared is 0.48 , while both the constant term and the trend coefficient are statistically significant at 1 per cent.

c The thick dotted lines represent \pm 2 per cent of the trend line, while the thin dotted lines represent \pm 1 per cent of the trend line. Sources: BIS web site (<www.bis.org/>); authors' estimations.

Finally, Ma and McCauley (2011a, 2011b) provide econometric evidence that in this twoyear period, the foreign exchange value of the RMB showed a tendency to revert to a mean defined by an upward crawl against its trade-weighted basket. Specifically, much in the manner of the Singapore-style exchange rate policy, the effective RMB seemed to describe a 2 per cent annual crawl within a \pm 2 per cent band (Figure 4.7 ). 
Nevertheless, the RMB abruptly returned to a tight peg against the US dollar in July 2008 and appreciated substantially in effective terms as a result of a stronger dollar. One possible explanation is that the Chinese authorities chose to revert to a reliable and trusted anchor at a time of significant financial market turbulence. The two-year experiment with basket management for the RMB was apparently interrupted in response to the deepening global financial crisis. A reversion to dollar stability allowed the effective RMB to pierce the upper edge of the estimated band on a steep appreciation path (Figure 4.7). Given the marked strength of the dollar in the latter part of 2008, the Chinese authorities would have had to allow a considerable decline in the RMB against the dollar in order to maintain effective exchange rate stability. This policy shift in RMB management would be consistent with broad policy concerns about sustained weakness of the RMB vis-a-vis the dollar, given structurally large Sino-US trade imbalances, as well as a new priority to anchor market confidence in times of global financial instability due to the dollar's safe-haven role.

With more normal trading conditions in global foreign exchange markets, the considerations that led to management of the RMB against its trading partners' currencies could come again to the fore. Indeed, the Chinese central bank announced in June 2010 that the 'special measure' of a return to a dollar peg in response to the global financial crisis would be dropped in favour of a return to a managed float in reference to a basket of currencies (PBC 2010b).

A RMB less tied to the dollar could be a more attractive currency in which to borrow, especially if the currencies of China's regional trading partners come to share its movement against the major currencies. The Asian experience from mid-2006 to mid-2008 suggested such co-movement between some East Asian currencies and the RMB. East Asian currencies managed against their respective trade-weighted currency baskets can show relative stability against each other, owing to the similarity of these baskets (Girardin 2011; Ma and McCauley 2011 a, 2011b). For instance, given similarities in basket composition, when the Chinese were managing the RMB's effective exchange rate and the Malaysians were managing the ringgit's effective exchange rate, the ringgit/RMB was fairly stable. This offers an informal approach for stabilising currencies both in effective terms (globally), which is important for these outward-oriented economies, and in bilateral terms within East Asia. Though it was overwhelmed by the effect of the global financial crisis on major currencies and capital flows in mid-2008, such an informal approach can create more favourable conditions for an evolution towards monetary cooperation over time in Asia. For present purposes, stability between the RMB and Asian currencies could make the RMB an attractive currency in which to borrow.

Through some combination of tighter trade links and management, East Asian currencies could come to trade with less volatility against the RMB than against the dollar, euro or yen. In this case, the RMB could serve as a natural currency in which firms and governments in the region would denominate their debts.

In sum, the notion that the RMB has been and therefore will remain basically in the orbit of the dollar requires that the evidence of a two-year experiment in 2006-08 be ignored. If the RMB is once again managed more broadly, there is no reason to consider that China's trading partners will find denominating their debts in the RMB uninteresting. 


\section{Conclusions}

The global financial crisis might make the rest of the world more open to taking on some of the currency risk in China's international balance sheet. China's interest in sharing some of that rapidly building risk predated the crisis. We interpret the recent policies adopted by the Chinese authorities as setting the stage for RMB internationalisation that would allow the rest of the world to denominate debt in RMB. But if trading partners consider that the RMB is subject to a big jump risk then near-term prospects for denominating more of China's foreign assets in RMB would be weak, though the wider external use of the currency through further building up of China's RMB-denominated foreign liabilities could even accelerate. And if trading partners dismiss the RMB simply as the US dollar with a greater or lesser trend appreciation then prospects for its internationalisation would also be weak. We have presented evidence to suggest that these views are easily overstated, and that therefore they understate the prospects over time for the internationalisation of the RMB in general and the renminbisation of China's external assets in particular.

Of course, full internationalisation ultimately requires a fully open capital account. The steps that China is taking should be seen as permitting internationalisation to begin within capital controls and so far mostly in the offshore RMB market based in Hong Kong. Lifting the remaining capital controls to allow the full internationalisation of the RMB remains a policy for another day.

\section{Bibliography}

Asian Development Bank (ADB) 2007, Purchasing Power Parities and Real Expenditures, December Asian Development Bank, Manila.

Bergin, P. R., Glick, R., Taylor, A. M. 2006, 'Productivity, tradability, and the long-run price puzzle', Journal of Monetary Economics, vol. 53, no. 8, pp. 2041-66.

Blanchard, O., Giavazzi, F. and Sa, F. 2005, The U.S. current account and the dollar, Brookings Papers on Economic Activity, no. 1, Brookings Institution, Washington, DC, pp. 1-66.

Chen, X. and Cheung, Y.-W. 2011, 'Renminbi going global', China \& World Economy, vol. 19, pp. 1-18.

Cheung, Y.-W. and Qian, X. W. 2010, 'Capital flight: China's experience', Review of Development Economics, vol. 142, pp. 227-47.

Cheung, Y.-W., Chinn, M. D. and Fujii, E. 2007, 'The overvaluation of renminbi undervaluation', Journal of International Money and Finance, vol. 26, pp. 762-85.

Cheung, Y.-W., Chinn, M. D. and Fujii, E. 2010a, 'Measuring misalignment: latest estimates for the Chinese renminbi', in S. Evenett (ed.), The US-Sino Currency Dispute: New insights from economics, politics and law, A voxeu.org Publication, Centre for Economic Policy Research, London, ch. 10, pp. 79-90.

Cheung, Y.-W., Chinn, M. D. and Fujii, E. 2010b, 'Measuring renminbi misalignment: where do we stand?', Korea and the World Economy, vol. 11, pp. 263-96. 
Cheung, Y.-W., Chinn, M. D. and Garcia Pascual, A. 2005, 'Empirical exchange rate models of the Nineties: are any fit to survive?', Journal of International Money \& Finance, vol. 24, pp. 1150-75.

Cheung, Y.-W., Ma, G. and McCauley, R. N. 2011, 'Renminbising China's foreign assets', Pacific Economic Review, vol. 16, pp. 1-17.

China Development Bank (CDB) 2009, Annual Report 2008, China Development Bank, Beijing.

Cline, W. R. and Williamson, J. 2010, Notes on equilibrium exchange rates, Policy Brief PB102, January, Peterson Institute for International Economics, Washington, DC.

Committee on the Global Financial System (CGFS) 2010, The functioning and resilience of cross-border funding markets, CGFS Report No. 37, March, Committee on the Global Financial System, Bank for International Settlements, Basel.

Cui, L., Chang, S. and Chang, J. 2009, 'Exchange rate pass-through and currency invoicing in China's exports', HKMA China Economic Issues, no. 2/09.

Dobson, W. and Masson, P. 2009, 'Will the renminbi become a world currency?', China Economic Review, vol. 20, pp. 124-35.

Dunaway, S. and Li, X. 2005, Estimating China's equilibrium real exchange rate, IMF Working Paper, WP/05/202, International Monetary Fund, Washington, DC.

Dunaway, S., Leigh, L. and Li, X. 2009, 'How robust are estimates of equilibrium real exchange rates: the case of China', Pacific Economic Review, vol. 14, pp. 361-75.

Elekdag, S. and Lall, S. 2008, 'International statistical comparison: global growth estimates trimmed after PPP revisions', IMF Survey Magazine, 8 January.

Fung, S., Klau, M., Ma, G. and McCauley, R. 2009, 'Implications of refined renminbi effective exchange rates with Asian entrepot and intra-regional trade', in Y.-W. Cheung and K.-Y. Wong (eds), China and Asia: Economic and financial interactions, Routledge, London, pp. 178-93.

Frankel, J. 2006, 'On the yuan: the choice between adjustment under a fixed exchange rate and adjustment under a flexible rate', CESifo Economic Studies, vol. 52, pp. 246-75.

Gao, H. and Yu, Y. 2011, 'Internationalisation of the renminbi', in Y.-W. Cheung and G. Ma (eds), Asia and China in the Global Economy, World Scientific Publishing, Singapore.

Genberg, H., McCauley, R., Persaud, A. and Park, Y.-C. 2005, Official reserves and currency management in Asia: myth, reality and the future, Geneva Reports on the World Economy No. 7, International Centre for Monetary and Banking Studies and Centre for Economic Policy Research, Geneva and London.

Girardin, E. 2011, A de facto Asian-currency unit bloc in East Asia: it has been there but we did not look for it, ADB Institute Working Paper No. 262, 14 January, Asian Development Bank, Manila.

Goldstein, M. and Lardy, N. 2009, Debating China's Exchange Rate Policy, Peterson Institute of International Economics, Washington, DC. 
Hu, C. and Chen, Z. 2010, 'Renminbi already overappreciated: evidence from FEERs (19942008)', China Economist, vol. 26, pp. 64-78.

International Monetary Fund (IMF) 2010a, People's Republic of China: 2010 Article IV consultation - Staff report, International Monetary Fund, Washington, DC, <http:// www.imf.org/external/pubs/ft/scr/2010/cr10238.pdf>

International Monetary Fund (IMF) 2010b, Review of the Method of Valuation of the SDR, 26 October, International Monetary Fund, Washington, DC.

International Monetary Fund (IMF) 2011, Recent Experiences in Managing Capital Inflows: Cross-cutting themes and possible policy framework, 14 February, International Monetary Fund, Washington, DC.

Kravis, I. B. and Lipsey, R. E. 1983, Toward an explanation of national price levels, Princeton Studies in International Finance No. 52, International Finance Centre, Princeton University, Princeton, NJ.

Kravis, I. B. and Lipsey, R. E. 1987, 'The assessment of national price levels', in S. W. Arndt and J. D. Richardson (eds), Real Financial Linkages Among Open Economies, MIT Press, Cambridge, Mass., pp. 97-134.

Kravis, I. B., Heston, A. and Summers, R. 1978, International Comparisons of Real Product and Purchasing Power, The Johns Hopkins University Press, Baltimore.

Japan Bank for International Cooperation (JBIC) 2008, Annual Report 2008, Japan Bank for International Cooperation, Tokyo.

Lane, P. R. and Shambaugh, J. C. 2010, 'Financial exchange rates and international currency exposures', American Economic Review, vol. 100, no. 1, pp. 518-40.

Ma, G. and McCauley, R. N. 2008, 'The efficacy of China's capital controls-evidence from price and flow data', Pacific Economic Review, vol. 13, pp. 104-23.

Ma, G. and McCauley, R. N. 2011a, 'The evolving renminbi regime and implications for Asian currency stability', Journal of the Japanese and International Economies, no. 25, pp. 23-38.

Ma, G. and McCauley, R. N. 2011b, 'The implications of renminbi basket management for Asian currency stability', in Y.-W. Cheung, V. Kakkar and G. Ma (eds), The Evolving Role of Asia in Global Finance, Emerald Group Publishing Limited, Bradford, UK.

Ma, G. and Zhou, H. 2009, China's evolving external wealth and rising creditor position, BIS Working Papers No. 286, Bank for International Settlements, Basel.

McCauley, R. 2010, 'Managing recent hot money inflows in Asia', in M. Kawai and M. Lamberte (eds), Managing Capital Flows in Asia: Search for a framework, Edward Elgar, Cheltenham, UK. 
McCauley, R. 2011, The internationalisation of the renminbi, Presented to Second Annual International Conference on the Chinese Economy, 'Macroeconomic Management in China: Monetary and financial stability issues', Hong Kong Institute for Monetary Research, 13-14 January 2011, <http://www.hkimr.org/cms/upload/news_app/ news_0_56_McCauley_speech_HKIMR_14Jan2011.pdf $>$

McCauley, R. and McGuire, P. 2009, 'Dollar appreciation in 2008: safe haven, carry trades, dollar shortage and overhedging', BIS Quarterly Review, December, pp. 85-93.

McCauley, R. and Scatigna, M. 2011, 'Foreign exchange trading in emerging currencies: more financial, more offshore', BIS Quarterly Review, March, pp. 67-75.

McGuire, P. and von Peter, G. 2009, 'The US dollar shortage in global banking', BIS Quarterly Review, March, pp. 47-63.

Meese, R. and Rogoff, K. 1983, 'Empirical exchange rate models of the Seventies: do they fit out of sample?', Journal of International Economics, vol. 14, pp. 3-24.

People's Bank of China (PBC) 2008, China's Monetary Policy Report, May, People's Bank of China, Beijing.

People's Bank of China (PBC) 2010a, China's Regional Financial Development in 2009, June, People's Bank of China, Beijing.

People's Bank of China (PBC) 2010b, Further reform of the RMB exchange rate regime and enhancement of the RMB exchange rate flexibility, Policy announcement, 19 June 2010, People's Bank of China, Beijing, <http://www.pbc.gov.cn/english/detail. asp?col=6400\&id $=1488>$

People's Bank of China (PBC) 2011, China's Monetary Policy Implementation Report for the Fourth Quarter of 2010, February, People's Bank of China, Beijing.

People's Bank of China and International Monetary Fund (PBC and IMF) 2009, Note Purchase Agreement Between the People's Bank of China and the International Monetary Fund, Beijing.

Samuelson, P. 1964, 'Theoretical notes on trade problems', Review of Economics and Statistics, vol. 46, no. 2, pp. 145-54.

Samuelson, P. 1994, 'Facets of Balassa-Samuelson thirty years later', Review of International Economics, vol. 2, no. 3, pp. 201-26.

State Administration of Foreign Exchange (SAFE) 2008, China Annual Balance of Payments Report 2007, [in Chinese], State Administration of Foreign Exchange, Beijing.

Stupnytska, A., Stolper, T. and Meechan, M. 2009, GSDEER on track: our improved FX fair value model, Global Economics Weekly No. 09/38, 28 October, Goldman Sachs Global Economics.

Subramanian, A. 2010, New PPP-based estimates of renminbi undervaluation and policy implications, Policy Brief PB10-18, April, Peterson Institute for International Economics, Washington, DC. 
Summers, R. and Heston, A. 1991, 'The Penn World Table (Mark5): an expanded set of international comparisons', Quarterly Journal of Economics, vol. 106, no. 2, pp. 327-68.

Takagi, S. 2011, 'Internationalisation of the yen: unfinished business or mission impossible?', in Y.-W. Cheung and G. Ma (eds), Asia and China in the Global Economy, World Scientific Publishing, Singapore.

Tenengauzer, D. 2010, 'RMB: the people's currency', EM FX and Debt Spotlight, 21 April, Bank of America-Merrill Lynch.

The Economist 2010, 'Our Big Mac index shows the Chinese yuan is still undervalued', Economist.com, 14 October 2010.

Tsang, S. 2010, Internationalisation and full convertibility of the renminbi, <http://www. sktsang.com/ArchiveIII/Tsang_RMB_20100717.pdf>

Wang, T. and Hu, H. 2010, 'How undervalued is the RMB?', Asian Economic Perspectives, 13 April, UBS Investment Research.

World Bank 2008a, Comparison of New 2005 PPPs with Previous Estimates: Appendix G revised-Global purchasing power parities and real expenditures, The World Bank, Washington, DC.

World Bank 2008b, Global Purchasing Power Parities and Real Expenditures: 2005 International Comparison Program, International Comparison Program and International Bank for Reconstruction and Development, The World Bank, Washington, DC.

Yu, Y. 2008, 'Panda bonds could help China avoid the risks of US Treasury bonds', East Asia Forum, 19 December, <http://www.eastasiaforum.org/2008/12/19/panda-bonds-couldhelp-china-avoid-the-risks-of-us-treasury-bonds/>

\section{Endnotes}

1. We thank Claudio Borio for his helpful comments and suggestions and Magdalena Erdem, Eric Chan and Lillie Lam for research assistance. Cheung acknowledges the financial support of faculty research funds of the University of California, Santa Cruz. The views expressed are those of the authors only and should not be interpreted as those of the Bank for International Settlements (BIS).

2. Indeed, since the introduction of cross-border trade settlements in RMB in 2009, the value of Chinese imports settled in RMB has been much larger than the value of Chinese exports settled in RMB. This has resulted in a noticeable build-up of RMB liquidity offshore, which is part of the RMB-denominated foreign liabilities on the balance sheet of the People's Bank of China. In other words, the currency mismatch on China's international balance sheet has become more acute in the short term as a result of the first steps towards RMB internationalisation.

3. In non-deliverable transactions, forward trades are settled in dollars because Chinese capital controls prohibit RMB to be paid out to offshore accounts without documentation of underlying trade transactions.

4. Only if dollar and euro-denominated bonds were perfect substitutes in investors' portfolios would such a diversification by China have no effect (much like sterilised intervention under the same assumption) (see Genberg et al. 2005).

5. The ultimate effect on the foreign exchange market would depend on the behaviour of the borrower from the IMF. If the latter received its SDR-denominated credit from the IMF in dollars, added the sum to its reserves, but sought to match its SDR-denominated liability then it would sell some of the dollars for euro, yen and 
sterling. Under these assumptions, the effect on the foreign exchange market would be much the same as if China itself had diversified from the dollar to the SDR. It should also be noted that by exchanging a dollar bond for the IMF bond, China would be diversifying by obligor as well as currency.

6. Offshore RMB are often described as if they are only in Hong Kong; indeed, as of 2010, more than 90 per cent of offshore RMB were concentrated in Hong Kong. But offshore RMB are also to be found in Kuala Lumpur and Singapore and could eventually be traded in other international financial centres. In early 2011, for instance, the Bank of China started offering RMB bank accounts and related services in New York.

7. See, for example, Cheung et al. (2010a, 2010b) for a discussion of these approaches.

8. For discussions about the 2005 International Comparison Program benchmark and the related data revision issues, see ADB (2007); Elekdag and Lall (2008); and World Bank (2008a, 2008b). 